\title{
Study on ascitic fluid protein level in cirrhotic patients with spontaneous bacterial peritonitis
}

\author{
M. Golam Mustafa, M. Ayub Al Mamun and A.K.M. Khorshed Alam \\ Department of Hepatology, Bangabandhu Sheikh Mujib Medical University, Dhaka, Bangladesh. \\ e-mail:m_golam@yahoo.com
}

\begin{abstract}
Complement 3 is an important component of ascitic fluid total protein, which offers local defence against infection of the ascitic fluid. Hepatic synthesis of complement 3 as well as other proteins and their concentrations in ascitic fluid is significantly reduced in patients with advanced cirrhosis. The level of protein in ascitic fluid in cirrhotic patients with spontaneous bacterial peritonitis was compared with that in patients without spontaneous bacterial peritonitis. Ascitic fluid protein level in spontaneous bacterial peritonitis $(\mathrm{n}=15)$ was $1.1 \pm 0.3 \mathrm{~g} / \mathrm{dL}$ whereas it was $1.5 \pm 0.5 \mathrm{~g} / \mathrm{dL}$ in patients without spontaneous bacterial peritonitis $(\mathrm{n}=15)$. In conclusion, this study suggests that, ascitic fluid protein level is significantly $(\mathrm{p}=0.008)$ reduced in cirrhotic patients who develop spontaneous bacterial peritonitis.
\end{abstract}

\section{Introduction}

Spontaneous bacterial peritonitis is a serious infection that occurs frequently in patients with advanced cirrhosis. This condition has been defined as the infection of a previously sterile ascitic fluid, without any apparent intra abdominal source of infection. Diagnosis of spontaneous bacterial peritonitis is based on ascitic fluid neutrophil count of $\geq 250 / \mathrm{cmm}$ (and/or leucocyte count of $\geq 500 / \mathrm{cmm})^{1}$. In the past, it was associated with a high mortality rate ${ }^{2}$. Prevalence of spontaneous bacterial peritonitis is as high as $18 \%$ in cirrhotic patients with ascites and mortality associated with the complication ranges from 40-70\%. During 1970 s, mortality in patients hospitalized for spontaneous bacterial peritonitis was 80-90\%. Since then, there has been an explosion of information about spontaneous bacterial peritonitis that has improved awareness of the condition. Occurrence of spontaneous bacterial peritonitis depends on the local immune response of the ascitic fluid.

Ascitic fluid C3 concentration and opsonic activities are important protective factors against spontaneous bacterial peritonitis. Liver is the main site of synthesis of complement components; C3 is the main component of complement system ${ }^{3}$. The C3 component of complement tends to be reduced in cirrhosis ${ }^{4}$. Patients with reduced ascitic fluid C3 concentration and reduced opsonic activities have been shown to be predisposed to spontaneous bacterial peritonitis ${ }^{5,6}$. As complements are important components of serum as well as ascitic fluid protein, ascitic fluid protein concentration is also reduced in patients of cirrhosis with spontaneous bacterial peritonitis.

Adequate laboratory parameters are lacking to detect patients at risk of developing spontaneous bacterial peritonitis. Ascitic fluid protein estimation is an easy biochemical test and can be done in any standard laboratory. The study was designed with the aim of assessing the correlation of ascitic fluid protein with the development of spontaneous bacterial peritonitis, thereby to serve as a parameter for selecting those at risk of developing this complication.

\section{Materials and Methods}

It was a prospective cross-sectional study to compare the level of ascitic fluid protein concentration in cirrhotic patients with and without spontaneous bacterial peritonitis and to observe the ascitic fluid protein level that correlates with the development of spontaneous bacterial peritonitis. The study was carried out during the period of July 2003 to June 2005.

Fourteen consecutive admitted patients and one out door patient of established cirrhosis with ascites were included in the study. Included patients had no existing evidence or past history of spontaneous bacterial peritonitis. 
Another 15 consecutive patients with cirrhotic ascites were included who were admitted with spontaneous bacterial peritonitis or developed spontaneous bacterial peritonitis during hospital stay.

Patients with hepatocellular carcinoma, grade IV encephalopathy, diabetes mellitus and previous episode of spontaneous bacterial peritonitis were excluded.

At the initial phase, a standard questionnaire was designed to record the detail data of patients. A thorough clinical and laboratory evaluation were done and the patients were categorised as per Child-Pugh class ${ }^{7}$.

About $30 \mathrm{~mL}$ of ascitic fluid was collected from each patient following standard aseptic technique; when needed the help of ultrasound guidance was taken.

Ascitic fluid cytology was done using improved neubauer counting chamber with Leishman stain. Ascitic fluid protein level was estimated by biuret colorimetric method. Ascitic fluid C3 was measured by liquid phase immunoprecipitation assay by turbidometry. For culture, about $10 \mathrm{~mL}$ of ascitic fluid was immediately inoculated into triptic soy broth medium containing bottle at the bedside.

Data of cirrhotic ascites patients with spontaneous bacterial peritonitis and without spontaneous bacterial peritonitis were collected as per specified variables. Comparative analysis of data of the two groups was made through standard statistical methods. All the data were processed and analysed by computerized SPSS programme. Significance of the test was tested by unpaired " $\mathrm{t}$ " test and " $\mathrm{x}$ ", test. A $p$ value of $<0.05$ was taken as statistically significant.

\section{Results}

Spontaneous bacterial peritonitis patients (males 12 , females 3 ) had mean ( \pm SD) age of $43 \pm 14$ years. Non-spontaneous bacterial peritonitis patients (males 14, female 1) had mean age of 40 \pm 12 years. They were of diverse occupation. All the patients in the spontaneous bacterial peritonitis group and eight patients in the non-spontaneous bacterial peritonitis group were in Child's grade "C". Seven patients in the non-spontaneous bacterial peritonitis group were in the Child's grade "B".

Eight patients in the non-spontaneous bacterial peritonitis group and 10 patients in the spontaneous bacterial peritonitis group were positive for HBsAg. One patient in the spontaneous bacterial peritonitis group and none in the non-spontaneous bacterial peritonitis group were positive for anti$\mathrm{HCV}$. Eleven patients were negative for viral markers.

Mean ascitic fluid total protein was $1.5 \pm 0.5 \mathrm{~g} / \mathrm{dL}$ in the non-spontaneous bacterial peritonitis group and $1.1 \pm 0.3 \mathrm{~g} / \mathrm{dL}$ in the spontaneous bacterial peritonitis group (Table I). Mean ascitic fluid C3 level was $16.4 \pm 11.3 \mathrm{mg} / \mathrm{dL}$ in the nonspontaneous bacterial peritonitis group and $7.3 \pm$ $4.3 \mathrm{mg} / \mathrm{dL}$ in the spontaneous bacterial peritonitis group.

Five spontaneous bacterial peritonitis patients $(33.33 \%)$ and no non-spontaneous bacterial peritonitis patients were culture positive. Of culture positive cases, $4(80 \%)$ were positive for Escherichia coli and $1(20 \%)$ was positive for Streptococcus fecalis. Anaerobic culture was not done.

Table 1 Shows biochemical and haematological parameters in ascitic fluid

\begin{tabular}{lcccc}
\hline \multirow{2}{*}{ Parameters } & \multicolumn{2}{c}{ Study groups } & t value & $\mathrm{p}$ value \\
\cline { 2 - 4 } & $\begin{array}{c}\text { Non-spontaneous } \\
\text { bacterial peritonitis }\end{array}$ & $\begin{array}{c}\text { Spontaneous } \\
\text { bacterial peritonitis }\end{array}$ & 2.911 & 0.008 \\
\hline Ascitic fluid protein (g/dL) & $1.5 \pm 0.5$ & $1.1 \pm 0.3$ & 2.920 & 0.009 \\
Ascitic fluid C3 (mg/dL) & $16.4 \pm 11.3$ & $2260 \pm 2023$ & 4.001 & 0.001 \\
Ascitic fluid WBC (cmm) & $152 \pm 145$ & $1261 \pm 1073$ & 4.343 & 0.001 \\
Ascitic fluid neutrophil (cmm) & $56 \pm 46$ & & & \\
\hline
\end{tabular}

\section{Discussion}

Spontaneous bacterial peritonitis is a severe and frequent complication of decompensated cirrhosis of liver with a high mortality rate. Patients with decompensated cirrhosis are characterised by presence of ascites and/or encephalopathy. Laboratory features of hepatic decompensation include raised serum bilirubin, low serum albumin and prolonged prothrombin time.

The liver is the most important site of synthesis of the serum proteins. The plasma proteins produced by the hepatocyte are synthesised on polyribosomes bound to the rough endoplasmic reticulum, from which they are discharged into plasma. The 
hepatocyte makes up albumin, fibrinogen,

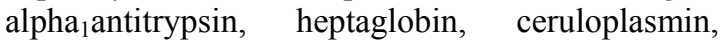
transferrin and prothrombin. Fall in concentration usually reflects decreased hepatic synthesis ${ }^{4}$. In cirrhosis, the hepatocytes undergo fibrosis due to continued inflammation by the inciting agent and lose their capacity to synthesize proteins. Among the proteins, complement 3 is important in offering defence against infection. Patients with low protein have low opsonic activity and therefore are at risk of developing spontaneous bacterial peritonitis ${ }^{8,9}$.

Recent investigations have shown that cirrhotic patients with low ascitic fluid $\mathrm{C} 3$ and low ascitic fluid total protein are more predisposed to spontaneous bacterial peritonitis ${ }^{10}$.

All cirrhotic patients might benefit from antibiotics if ascitic fluid protein is $<1.0 \mathrm{~g} / \mathrm{dL}^{11}$. Patients with ascitic fluid protein $<15 \mathrm{~g} / \mathrm{L}$ and either Child-Pugh Score of at least 9 or impaired renal function may also benifit ${ }^{12}$.

In our study, ascitic fluid protein was $1.1 \pm 0.3$ $\mathrm{g} / \mathrm{dL}$ in the cases of spontaneous bacterial peritonitis and $1.5 \pm 0.5 \mathrm{~g} / \mathrm{dL}$ in the nonspontaneous bacterial peritonitis group. The difference of findings between the two groups is highly significant $(p=0.008)$. The protein level in the ascitic fluid of patients who developed spontaneous bacterial peritonitis $(1.1 \pm 0.3 \mathrm{~g} / \mathrm{dL})$ was significantly lower than the protein level in the ascitic fluid of those who did not develop spontaneous bacterial peritonitis $(1.5 \pm 0.5 \mathrm{~g} / \mathrm{dL})$.

In the study, $\mathrm{C} 3$ concentration of $7.3 \pm 4.3 \mathrm{mg} / \mathrm{dL}$ was found in the ascitic fluid of patients who developed spontaneous bacterial peritonitis and $16.4 \pm 11.3 \mathrm{mg} / \mathrm{dL}$ was found in the ascitic fluid of those who did not develop spontaneous bacterial peritonitis. The difference of $\mathrm{C} 3$ concentration between the spontaneous bacterial peritonitis and non-spontaneous bacterial peritonitis group is highly significant statistically $(\mathrm{p}=0.009)$.

Culture was positive in $33.3 \%$ of cases of spontaneous bacterial peritonitis, which included Escherichia coli in 4 patients $(80 \%$ of culture positive cases) and Streptococcus fecalis in one patient (20\% of culture positive cases). Culture positivity is lower in this study.

From the study, it is clear that, ascitic fluid protein as well as C3 both is reduced in patients with spontaneous bacterial peritonitis. As C3 is a component of ascitic fluid total protein, ascitic fluid protein estimation may reflect roughly the level of $\mathrm{C} 3$. In conclusion, ascitic fluid protein level is significantly reduced in Bangladeshi cirrhotic patients who develop spontaneous bacterial peritonitis. Prompt prophylactic measures against spontaneous bacterial peritonitis to be taken in cirrhotic patients with low ascitic fluid protein level. But, as the study was limited by a small sample size, we recommend further study to determine a level of ascitic fluid protein, which can predict the development of spontaneous bacterial peritonitis.

\section{References}

1. Thomas D, Boyer TD. Diagnosis and management of cirrhotic ascites. In: Hepatology: A textbook of liver disease. $4^{\text {th }}$ ed. Philadelphia, Sounders, 2003, p 639.

2. Bass NM. Intravenous albumin for spontaneous bacterial peritonitis in patients with cirrhosis. New Engl J Med. 1999; 341: 443-44.

3. Wyke RJ, Rajkovic IA, Eddleston AL, Williams R. Defective opsonisation and complement deficiency in serum from patients with hepatic failure. Gut 1980; 21: 643-49.

4. Sherlock S, Dooley J. Assessment of liver function. In: Disease of the liver and biliary system. $11^{\text {th }}$ ed. Oxford, Blackwell Science, 2002, p 32-33.

5. Such J, Guarner C, Enriquez J, Rodriguez JL, Seres I, Vilardell F. Low C3 in cirrhotic ascites predisposes to spontaneous bacterial peritonitis. J Hepatol. 1988; 6: 8084.

6. Runyon BA. Patients with deficient ascitic fluid opsonic activity are predisposed to spontaneous bacterial peritonitis. Hepatology 1988; 8: 632-35.

7. Hayes PC, Simpson KJ, Garden OJ. Liver and biliary tract disease. In: Davidson's Principles and Practice of Medicine. $19^{\text {th }}$ ed. Edinburgh, Churchill Livingstone, 2002, p 850 .

8. Rajkovic IA, Williams R. Abnormalities of neutrophil phagocytosis, intracellular killing and metabolic activity in alcoholic cirrhosis and hepatitis. Hepatology 1986; 6: 252-62.

9. Rimola A, Soto R, Borly F, Arroyo V, Piera C, Rodes J. Reticuloendothelial system phagocytic activity in cirrhosis and its relation to bacterial infections and prognosis. Hepatology 1984; 4: 53-58.

10. Mal F, Huu TP, Bendahou M, Trinchet JC, Garnier M, Hakim J, Beaugrand M. Chemoattractant and opsonic activity in ascitic fluid, a study in 47 patients with cirrhosis or malignant peritonitis. J Hepatol. 1991; 12: 45-49.

11. Runyon BA. Low protein concentration in ascitic fluid is predisposed to spontaneous bacterial peritonitis. Gastroenterology 1986; 91: 1343-46.

12. Fernández J, Navasa M, Planas R, Montoliu S, Monfort D, Soriano G, Vila C, Pardo A, Quintero E, Vargas V, Such J, Ginès P, Arroyo V. Primary prophylaxis of spontaneous bacterial peritonitis delays hepatorenal syndrome and improves survival in cirrhosis. Gastroenterology 2007; 133: 818-24. 